\title{
The Effect of Affiliate Needs Towards Cybersex on Male Adolescent Users of Online Dating Application
}

\author{
Maharany Adhytya Kesumawardhany, Naufal Alifian Nugroho, Retno Dwiyanti* \\ Faculty of Psychology, Universitas Muhammadiyah Purwokerto Indonesia
}

*Corresponding author: retnodwiyanti@ump.ac.id

Article history: Received: 11 January 2020 Received in revised form: 28 June 2020 Accepted: 10 May 2021 Published online: 09 August 2021

\begin{abstract}
When it blooms once the use of applications dating online, who used male adolescents to mutually acquainted and interact with your opponent types, online dating application users initially only craved having a relationship with someone else, however, the passage of time of application of dating online is not only used as a place to get acquainted but to do cybersex. The research is aimed to know how to influence the needs of affiliates against cybersex on a male adolescent who used the application of dating online. Subject research, as much as 42 male adolescents who used the form of dating online, aged 18-40 years old, method of analysis is using methods quantitative. Collecting the data in the study is using a scale Likert, namely the scale of the needs of affiliates, with the reliability of 0.902 and scale cybersex with a coefficient of reliability of 0.816 . Analysis of the data used is a test of linear regression simple, earned value F of 0.403 and Sig $=0,000(\mathrm{P}>0.001)$, it can be concluded that the need for affiliation has no effect on cybersex. The coefficient of determination (R Square) of 0.042 , which has a meaning that influences the need of affiliates against cybersex, amounted to $4.2 \%$.
\end{abstract}

Keywors: Applications Dating Online; Cybersex, Needs Affiliate.

C 2021 Penerbit UTM Press. All rights reserved

\subsection{INTRODUCTION}

Nowadays, the progress of the era is experiencing modern developments. Included in the field of technolog, one of which is an information technology product, namely the internet. Technology internet adult is increasingly growing rapidly even become media classified as very important in life. Internet into a container that holds a variety of information sharing from around the corners of the world so that the much used people to search for information that is needed. The internet has advantages, one of which has advantages: information that can be accessed from various places without limited distance, space and time (in Young, Knudson, and Boeis, 2004). Thus enabling each individual to obtain information that relates to the needs of those with access to information to various sources of information that exist on the internet (Novianto, 2011).

Indonesia is a developing country in the world, starting to feel the importance of using the internet. This also began to be realized by Indonesian people from various walks of life. Evidenced by internet statistics world data in Asia especially Indonesia regarding the number of internet users in Indonesia which continues to experience a significant increase. The latest data in June 2019, users have reached 171,260,000 (https://www.internetworldstats.com/asia.htm\#id).

The development of the internet has a major influence on technology in the field of communication. According to a survey conducted by Kompas Research and Development in 2015 (in Putu et al., 2017) to 6000 respondents in 15 major cities of Indonesia, 84.9\% access the internet via smart cellphones (smartphones).

The development of technology in the field of communication is the birth of various social media, which can be accessed online, supported by internet devices. With the presence of social media, communication and interaction activities for users will be more easily established, because communication and interaction activities in the online world can be established more broadly, such as without being limited by distance and time (Cessea \& Lestari, 2017).

The rise of social media, especially online dating applications that are used today such as Tinder, Badoo, OkCupid, BeeTalk, MeChat, and others. There are also online dating applications in the form of anonymous chat rooms wherein the chat rooms don't know each other's data. The application is used to communicate with each other in cyberspace. Online dating applications are specifically designed as social media to find a mate or can be called online dating that is supported by applications that use the internet and satellite navigation systems that regulate specific distances and locations to bring together a new partner or friend for users. The online dating application can be downloaded for free via an Android smartphone or iOS on the Play Store or Apple Store.

The rapid development of the internet with all the advantages and benefits including the field of communication media turned out to also cause problems, namely the emergence of the phenomenon of cybersex which became the public spotlight. According Purwono (in Rahmawati, Hadjam, \& Afiatin, 2002) states that the internet apparently not only displays pornographic sex in still images, but also there are moving images with sound, video clips with short duration to long duration. Cybersex occurs when someone uses the internet as a medium of interaction with others to get sexual satisfaction. 
Based on the studies preliminary carried out to 15 men with a range of ages 20-25 years who have a background education and employment are different. The results of a preliminary study stated that all subjects had done cybersex with various types. Starting from just a look at the pictures of erotic, use porn sites to do the chat sex, call sex,and sex video call is done by looking for a virtual pair from world virtual of abuse applications dating online (Tinder, MeChat, Secreto, OKCupid, Hago, and Bigo) that they download. The reason they do cybersex is because they have a desire or sexual arousal that can not be controlled because of male hormonal and fantasy or fantasy that is supported by pornographic images or videos on the sites. So there is a desire for sex that cannot be channeled. This makes men especially look for other ways to channel their passion. One of the methods they found was in an application that could be used to do cybersex like sexting, phone sex / call sex, video call sex. Then some people prefer to do cybersex because they feel bored or lonely. In fact personal needs that are not fulfilled or are not satisfied because of the loneliness experienced by individuals. Feeling that there is a desire to have people closest to either friends or partners who can understand them. Feeling the need for the presence of others makes individuals try to search in cyberspace, when it is felt the real world does not meet these needs.

In early adulthood, individuals try to build intimacy in relationships with others, especially in the opposite sex. Because it is in accordance with the opinion of Havighurst (in Monks, Knoers and Haditono, 2001) the task of early adult development is to marry or build a family, manage the household, educate or care for children, assume responsibility as citizens, make connections with a social group certain, and do a job. Studies conducted by Edelstein, Chopik, and Kean (Edelstein, Chopik, \& Kean, 2011) state that single or unmarried men tend to have high sex drive because they do not have a permanent partner to channel their sex drive. Men are said to be figures that are classified as vulnerable to risky sexual behavior, even more vulnerable than women.

Based on the studies earlier who do Carvalheira and Gomes (2003) states that the age of 15-19 years most many do cybersex, followed by the age of 20-24 years. In line with the research that is carried out by Cooper, Daneback, and Mansson (2005) find that usian 18-24 years most many do cybersex. Adolescent men who are cybersex actors each have different backgrounds both in terms of education and employment. Many things that encourage a man to do cybersex to addiction, one of which is the need for affiliation.

Based on the results of a preliminary study on 15 men with an age range of 20-25 years the results stated that people who tend to do cybersex are those who are known as individuals who have active interactions with others. This is indicated by their saying that they have empathy and sympathy and live in a close environment with other people whether family, friends or friends, even couples. They are fairly easy to give trust to others even though they just know because they have a strong urge to get acquainted and keep the relationship maintained. Although, in online dating applications or new chat applications to know the other person, they give confidence by opening up, telling life, or even expressing what they want.

As a previous study by Karsinta (2017) stated that extrovet personality types tend to behave in severe cybersex that is equal to $22.8 \%$. McCrae \& Costa (in Karsinta, 2017) explained that extroverts have the ability to establish relationships with the outside world. These personality characteristics can be seen through the breadth of an individual's relationship with the surrounding environment and the ability to establish relationships with other individuals, especially when in a new environment.

Based on the description above, it can be concluded that what affects a man in doing cybersex is the need for affiliation. Therefore, researchers are interested in examining how the influence of affiliation needs in early adult men who commit cybersex by conducting a study entitled: "The Effect of Affiliate Needs Against Cybersex in Early Adult Men Users of Online Dating Application Users".

\subsection{LITERATURE REVIEW}

According to Cooper (1999) cybersex namely the activities of individuals in using the internet to the activity of pleasure sexually, like seeing pictures of erotic, participating in chats about sex, mutual exchange swap images vulgar or email about sex, and so forth, which sometimes support the occurrence of masturbation. That is activity sex is online involves a pair of virtual or real and different sexual activities.

Cooper (in Boies, Knudson, \& Young, 2004) proposed four basic aspects or components of online sexual behavior namely activity, reflection , pleasure, and stimulation . Cooper, Daneback, and Mansson, 2005 (in Agustina \& Hafiza, 2013) suggested that cybersex creativity on the internet can be achieved through chat rooms and news groups. Forms of behavior cybersex one of them is real time with a couple of fantasy or chat that contains the chat erotic with friends chat in the room talking too much discussed when this, even several people to use the camera web to see couples them in a room talking (Carvalheira \& Gomes, 2003).

Maslow (in Hall \& Lindzey, 1993) states that the need for affiliation is the social needs of friends, loved and loved and accepted in their group relationships and environment. Humans basically always want to live in groups and no one is alone in a remote place. According Mc.Clelland ( in Rinjani \& Firmanto, 2013) need for affiliation is a need for people to be a sense of warm and encouragement in conjunction with others, the need is to encourage that behavior behavior creates a relationship as intimate with another person. That is the individual in the push to become people who are friendly, building a relationship that is warm to the others, and then trying to keep the relationship it as well as possible.

According to McClelland (in Rupawanti, 2008) aspects of affiliate needs are:

1) Prefer to be with other people rather than alone; basically, preferring to be with other people rather than alone, this is based on the age where he wants to break away from the family environment.

2) Frequently interact with other people; the tendency to find new environments and make friends more automatically makes teenagers interact more with other people (likes to get along).

3) Want to be liked and accepted by others; occurs because of the urge of desire that is to get recognition from others and to increase self-esteem.

4) Pleases others; one desire is to get recognition from the environment in which he or his group is located. To fulfill it, try to be a pleasant person for others.

5) Show and maintain a loyal attitude towards friends; because the need to be recognized, valued and dependent on the group so that it has a fear of loss that automatically makes it loyal to friends. 
6) Looking for approval and agreement of others; when faced with a problem, in terms of taking a stand and deciding he always needs someone else to solve it.

\subsection{METHODOLOGY}

In this study there are two variables, namely the independent variable (Affiliate needs) and the dependent variable (Cybersex). The population in this study are early adult users of online dating applications whose numbers are unknown and can be categorized into infinite categories. An infinite population or infinite population is a population whose borders cannot be found, so that it cannot be expressed in terms of quantitative quantities (Burhan, 2009).

The sampling technique in this study is using a non-probability technique that is incidental sampling technique. In this study the authors in this study at least the authors must take data from a sample of 42 people. Data collection methods used in this study are using the Cybersex scale and the scale of affiliation requirements. Data collection techniques used in this study are Likert scale models. The cybersex scale amounts to 40 items with many falling 6 items. The cybersex scale has a validity that moves from 0.337 to 0.781 . The reliability coefficient using Cronbach's alpha was 0.902 . The scale of affiliation needs amounts to 40 items with many falling 11 items. The scale of affiliation requirements has a range of validity ranging from 0.315 to 0.696 . The reliability coefficient using Cronbach's alpha was 0.816 .

\subsection{RESULTS \& DISCUSSION}

Researchers conducted a hypothesis test using F test, obtained based on the calculation as shown on the table 1 the significance value for the needs of affiliates and cybersex amounted to $0,000<0.05$ and Fcount value of $0.403<$ Ftable 4.08 , thus it can be concluded that there is no influence of interpersonal communication needs of affiliates on cybersex in Male adolescent users of online dating applications.

Researchers conducted a $\mathrm{T}$ test that had a t-value greater than the t-table value. The significance value for the influence of affiliation needs on cybersex is found to be $0,000<0.05$ and tcount value is $5.438>$ table 2.021 . Therefore, it can be concluded that there is a significant influence on the significance of affiliation needs in cybersex on male adolescent users of online dating applications.

Table 1 Results of the simple linear regression equation

\begin{tabular}{|c|c|c|c|c|c|}
\hline Model & Unstandardized Coeff & & & $\mathbf{t}$ & Sig. \\
\hline & B & Std. Error & Beta & & \\
\hline (Constant) & 103.560 & & 19.045 & 5.438 & .000 \\
\hline Need of Aff & -.386 & .291 & -.205 & -1.327 & .192 \\
\hline
\end{tabular}

\footnotetext{
a. Dependent Variable: Cybersex

Based on the table above it is known that the value of the contant $(\alpha)$ is 103,560 , while the value of affiliation requirements (B / coefficient of regression) is -0.386 so that the regression equation can be written as follows:

$\mathrm{Y}=\alpha+\mathrm{Bx}$

$\mathrm{Y}=103.560-0.386 \mathrm{x}$
}

The constant of 103,560 implies that the consistent value of cybersex is 103,560, while the regression coefficient of affiliation needs of 0.386 states that every $1 \%$ increase in the value of affiliation needs, the cybersex value increases by -0.386 , the coefficient is of minus value, so it can be concluded that the affiliation needs have an effect on negative to cybersex.

Table 2 Value of R Square

\begin{tabular}{|c|c|c|c|}
\hline Model & $\mathbf{R}$ & R Square Adjusted R Square & Std. Error of the Estimate \\
\hline 1 & $.205 \mathrm{a}$ & 15.247 & \\
\hline $\begin{array}{l}\text { a. } \\
\text { b. }\end{array}$ & $\begin{array}{l}\text { Predict } \\
\text { Depend }\end{array}$ & $\begin{array}{l}\text { (Constant), Kebutuhan_Afiliasi } \\
\text { Variable: Cybersex }\end{array}$ & \\
\hline
\end{tabular}

Based on the table 2 explains the magnitude of the correlation value $(\mathrm{R})$ that is equal to 0.205 . From the output obtained a coefficient of determination (R Square) of 0.042 which means that the influence of affiliation needs on cybersex is $4.2 \%$. This research is a simple linear regression study to analyze the influence of the needs of affiliates on cybersex in male adolescent users of online dating applications. Data collection is to use 40 item scales for affiliate needs and 40 item cybersex scales to 42 male adolescent users of online dating applications with a range of ages $18-40$ years.

The constant of 103,560 implies that the consistent value of cybersex is 103,560, while the regression coefficient of affiliation needs is 0,386 stating that every $1 \%$ increase in the value of affiliation needs, the cybersex value increases by -0.386 , the coefficient is minus, so it can be concluded that the affiliation needs negative effect on cybersex.

This is reinforced by the results of a previous study by Karsinta (2017) saying that personality types influence individuals on cybersex behavior. Where respondents who have introverted personality types are $25.3 \%$ and respondents who have extroverted personality types 
are $22.8 \%$. The results of the analysis of this study indicate that individuals are aware of matters related to sex so that they seek information themselves about sex and then like solitude.

According to Lestari (2012) said that people who do cybersex can hide their identity behind computer anonymity so that privacy is more awake, free to change partners, can assemble fantasy fantasies about the look on the faces of even couples.

Cybersex is done by early adult men through online dating applications because of the many underlying reasons. Not just the desire to have relationships or other affiliate needs. However, the feeling of boredom or loneliness is felt. Cybersex is considered to be able to provide excitement or satisfaction, so many men use cybersex as a gift to themselves for having gone through or doing something.

Men are said to be figures that are classified as vulnerable to risky sexual behavior, even more vulnerable than women. This is reinforced by studies conducted by Edelstein, Chopik, and Kean (2011) stating that single or unmarried men tend to have high sex drive because they do not have permanent partners to channel their sex drive.

Askun and Ataca (2007) say that men are classified as sexually proactive, controlling sexual contact and also more permissive in terms of sexuality. Meanwhile, the possession of large numbers of partners is seen as a sexual acknowledgment (Paul, McManus, \& Heyes, 2000), especially for men. Having a large number of sex partners makes a man feel great and get recognition from peers.

\subsection{CONCLUSION}

Based on the results of research on the influence of affiliation needs on cybersex in early adult users of online dating applications, the conclusion is that there is no significant effect. Obtained a coefficient of determination (R Square) of 0.042 which means that the influence of affiliation needs on cybersex is $4.2 \%$. Limitations in this study are the limited aspects that can affect cybersex. In this research, it is not discussed what aspects of cybersex are able to influence significantly.

\section{References}

A gustina, I., \& Hafiza, F. (2013). Religiositas dan Perilaku Cybersex Pada Kalangan Mahasiswa. PSIKOLOGIKA, 18(1), 15-23.

Boies, S.C., Knudson, G., \& Young, J. (2004). The Internet, Sex, and Youths: Implications for Sexual Development. Sexual Addiction and Compulsivity, 11(4), 343363. https://doi.org/10.1080/10720160490902630

Carvalheira, A., \& Gomes, F.A. (2003). Cybersex in Portuguese Chatrooms: A Study of Sexual Behaviors Related to Online Sex. Journal of Sex and Marital Therapy, 29(5), 345-360. https://doi.org/10.1080/00926230390224729

Cessia, K.D., \& Lestari, S.B. (2017). Pemahaman Pengguna Media Sosial Tinder Terhadap Fenomena Kencan Online Untuk Menjalin Hubungann Romantis Bagi Penggunanya. Interaksi Online, 6(1), 1-10. Retrieved from https://ejournal3.undip.ac.id/index.php/interaksi-online/article/view/19116. Retrieved date: 01 January 2020.

Daneback, K., Cooper, A., \& Månsson, S.A. (2005). An Internet Study of Cybersex Participants. Archives of Sexual Behavior, 34(3), 321-328. https://doi.org/10.1007/s10508-005-3120-Z

Edelstein, R.S., Chopik, W.J., \& Kean, E.L. (2011). Sociosexuality Moderates the Association Between Testosterone and Relationship Status in Men and Women. Hormones and Behavior, 60(3), 248-255. https://doi.org/10.1016/j.yhbeh.2011.05.007

Hall, C.S. \& Lindzey, G. (1993). Psikologi Kepribadian 2: Teori-Teori Holistik (Organismik-Fenomenologis). Yogyakarta: Kanisius

Karsinta, v. D. (2017). Hubungan Adiksi, Kontrol Diri Dan Tipe Kepribadian Terhadap Perilaku Cybersex Pada Remaja Sekolah Lanjut Tingkat Atas Di Kubu Raya (Doctoral dissertation).

Monk, F.J., Koners, A.M.P., \& Hadinoto, S.R. (2001). Psikologi Perkembangan: Pengantar Dalam Berbagai Bagiannya. Yogyakarta: Gajah Mada University Press. Novianto, I. (2011). Perilaku Penggunaan Internet Di Kalangan Mahasiswa (Studi Deskriptif Tentang Perilaku Penggunaan Internet Dikalangan Mahasiswa Perguruan

Tinggi Negeri (FISIP UNAIR) dengan Perguruan Tinggi Swasta (FISIP UPN) untuk Memenuhi Kebutuhan Informasinya). FISIP UNAIR: Surabaya.

Putu, N., Manu, C., Ayu, I.D., Joni, S., Luh, N., Purnawan, R., \& Mateen, J. (2017). Self-Disclosure Pengguna Aplikasi Kencan Online (Studi Pada Tinder).

Universitas Udayana, 1(1), 1-9.

Rahmawati, V.D., Hadjam, N.R., \& Afiatin, T. (2002). Hubungan Antara Kecenderungan Perilaku Mengakses Situs Porno Dan Religiusitas Pada Remaja. Jurnal Psikologi, (1), 1-13.

Rinjani, H., \& Firmanto, A. (2013). Kebutuhan Afiliasi Dengan Intensitas Mengakses Facebook Pada Remaja. Jurnal Imiah Psikologi Terapan, O1(01), 76-85.

Rupawanti, T.S. (2008). Hubungan Kebutuhan Afiliasi Dengan Perilaku Konsumtif Pada Remaja. Skripsi, Universitas Muhammadiyah Malang.

Young, J., Knudson, G., \& Boeis, S.C. (2004). The Internet, Sex, and Youths: Implications for Sexual Development. Sexual Addiction \& Compulsivity, $11,343-36$. 